\title{
Expression of endothelin receptor subtypes in bronchial tumors
}

\author{
SABINE BLOUQUIT-LAYE ${ }^{1}$, AGATHE REGNIER $^{2}$, ALAIN BEAUCHET ${ }^{3}$, \\ UTE ZIMMERMANN $^{2}$, PHILIPPE DEVILLIER ${ }^{1}$ and THIERRY CHINET ${ }^{1}$
${ }^{1}$ Université de Versailles Saint Quentin en Yvelines, UPRES EA220, Hôpital Foch, 11 rue Guillaume Lenoir, 92150 Suresnes; ${ }^{2}$ Laboratoire d'Anatomie Pathologique, ${ }^{3}$ Département de Santé Publique, \\ Hôpital Ambroise Paré, 9 av. Charles de Gaulle, Boulogne Billancourt, France
}

Received September 23, 2009; Accepted November 9, 2009

\section{DOI: $10.3892 /$ or_00000655}

\begin{abstract}
The importance of endothelin-1 (ET-1) in cell growth, migration and stimulation of angiogenesis suggests that ET-1 may play a role in tumor progression. The expression of the ET-1 receptors ETA $\left(\mathrm{ET}_{\mathrm{A}} \mathrm{R}\right)$ and $\mathrm{ETB}\left(\mathrm{ET}_{\mathrm{B}} \mathrm{R}\right)$ was analyzed by immunohistochemistry in fragments of human lung carcinomas. Samples were obtained from 11 patients with adenocarcinoma (ADK), 12 with squamous cell carcinoma (SCC) and 8 patients with small cell carcinoma (SCLC). Morphologically normal airway areas adjacent to the tumors served as controls. ADK and SCC samples had $\mathrm{ET}_{\mathrm{A}} \mathrm{R}$ and $\mathrm{ET}_{\mathrm{B}} \mathrm{R}$ levels similar to normal tissues; however, the $\mathrm{ET}_{\mathrm{A}} \mathrm{R} / \mathrm{ET}_{\mathrm{B}} \mathrm{R}$ ratio was higher in $\mathrm{ADK}$ than in SCC. We also observed the presence of endothelin receptors in SCLC, although the $\mathrm{ET}_{\mathrm{A}} \mathrm{R}$ levels and the ratio $\mathrm{ET}_{\mathrm{A}} \mathrm{R} / \mathrm{ET}_{\mathrm{B}} \mathrm{R}$ were lower than in normal tissue and in other carcinomas. In conclusion, both $\mathrm{ET}_{\mathrm{A}} \mathrm{R}$ and $\mathrm{ET}_{\mathrm{B}} \mathrm{R}$ are present in lung carcinomas but at different levels, according to the histological type of tumor.
\end{abstract}

\section{Introduction}

The endothelin (ET) family is comprised of four homologous 21 amino acid peptides, ET-1, ET-2, ET-3 and ET-4 (1). All ET isoforms arise from post-translational processing of preprohormones. ET-1 is the most abundant and extensively studied isoform and is also the most relevant in human cardiovascular physiology and pathophysiology $(1,2)$. Areas of ET production and binding sites for ET usually coexist, suggesting possible local effects. In the human lung, ET-1 is mainly produced by endothelial cells, airway epithelial cells

Correspondence to: Dr Sabine Blouquit-Laye, UPRES EA 220, 11 rue Guillaume Lenoir, 92150 Suresnes, France E-mail: blouquit@yahoo.fr

Key words: endothelin-1, receptors, lung, carcinoma, immunohistochemistry and alveolar epithelial cells $(3,4)$ and ET-1 binding sites are found in bronchial smooth muscle cells, endothelial cells, nerves, bronchial and bronchiolar epithelial cells, including glandular cells and alveolar epithelial cells (3-5).

ET-1 exerts numerous biological effects, including vasoconstriction, cell proliferation, epithelial ion transport and cell migration (1-3,6-8). There are 2 types of ET receptors (ETR): the ETA receptors $\left(\mathrm{ET}_{\mathrm{A}} \mathrm{R}\right)$ and the $\mathrm{ET}_{\mathrm{B}}$ receptors $\left(\mathrm{ET}_{\mathrm{B}} \mathrm{R}\right)$. The $\mathrm{ET}-1 / \mathrm{ET}_{\mathrm{A}} \mathrm{R}$ system stimulates the proliferation of several airway cells such as epithelial, bronchial and vascular smooth muscle cells (9-12). The ET-1/ET $\mathrm{ET}_{\mathrm{B}} \mathrm{R}$ system induces bronchoconstriction in addition to the migration and proliferation of endothelial cells $(8,10,13,14)$. Some ET-1 effects involve both receptors; for example, Sato et al (8) showed that blockade of both $\mathrm{ET}_{\mathrm{A}} \mathrm{R}$ and $\mathrm{ET}_{\mathrm{B}} \mathrm{R}$ is required for the complete inhibition of ET-1-induced vasoconstriction in the rat pulmonary circulation. On the other hand, the stimulation of $\mathrm{ET}_{\mathrm{B}} \mathrm{R}$ may counteract some of the ET-1/ET ${ }_{\mathrm{A}} \mathrm{R}$ system effects, for example by leading to vasodilatation or inhibition of epithelial cell proliferation $(1,7,12) . \mathrm{ET}_{\mathrm{B}} \mathrm{R}$ is also involved in the clearance of ET-1 from the circulation; therefore, the blockade of $\mathrm{ET}_{\mathrm{B}} \mathrm{R}$ may result in enhanced ET-1 activity via $\mathrm{ET}_{\mathrm{A}} \mathrm{R}(3,7,8,15,16)$. This clearance primarily takes place in the pulmonary circulation (16).

The importance of ET-1 in cell growth, cell migration and angiogenesis suggests that ET-1 may play a role in tumor progression. Increased expression of ET-1 has been reported in various human cancers such as ovarian, breast, colorectal, bladder, renal and prostate cancer (17-22). ET-1 expression is also increased in several lung cancer cell lines (23) and in freshly excised fragments of non-small cell lung carcinomas $(24,25)$. ET-1 levels are also increased in the breath condensate of patients with non-small cell lung cancer and this increase may be associated with poor prognosis $(25,26)$. In addition, elevated ET-1 concentrations in the saliva of oral cancer patients or breath condensate of lung cancer patients has been proposed as indicators to monitor patients at risk for oral or lung carcinoma $(26,27)$. Several studies have provided evidence that ET-1 is involved in proliferation and migration of cancer cells such as prostate, melanoma, colorectal and ovarian cancer cells $(18,28-31)$. In non-small cell lung carcinomas (NSCLC) and in breast carcinomas, a positive 
correlation has been found between ET-1 and the expression of vascular endothelial growth factor (VEGF) mRNA, suggesting that ET-1 might be involved in angiogenesis in these carcinomas $(25,32)$.

Depending on the type of cancer, $\mathrm{ET}_{\mathrm{A}} \mathrm{R}$ and $\mathrm{ET}_{\mathrm{B}} \mathrm{R}$ levels may be maintained, increased or decreased, which is likely to affect the biological effects of ET-1 (20). We therefore decided to investigate by immunohistochemistry the localization and distribution of $\mathrm{ET}_{\mathrm{A}} \mathrm{R}$ and $\mathrm{ET}_{\mathrm{B}} \mathrm{R}$ in tumors obtained from patients suffering from various types of lung carcinomas.

\section{Materials and methods}

Surgical specimens. Lung samples were obtained from patients who underwent curative surgical resection for lung cancer and gave their informed consent, in accordance with the current French legislation. The histological types of the primary tumors were squamous cell carcinoma (SCC, 12 patients, mean age $73 \pm 3$ years), adenocarcinoma (ADK, 11 patients, mean age $66 \pm 3$ years) and small cell lung carcinoma (SCLC, 8 patients, mean age $74 \pm 4$ years). In 5 of the above patients ( $3 \mathrm{ADK}$ and 2 SCC), samples of morphologically normal bronchi were dissected at sites distant from the tumor. One fragment of normal lung was also obtained from a smoker patient who died of head trauma and had no lung disease (21 pack-years, 45 years old). A sample of prostatic adenocarcinoma served as a positive control for $\mathrm{ET}_{\mathrm{A}} \mathrm{R}$ antibody specificity, as it has been shown that this tissue expresses high levels of $\mathrm{ET}_{\mathrm{A}} \mathrm{R}$ and no or low levels of $\mathrm{ET}_{\mathrm{B}} \mathrm{R}(19,32)$. The positive control for $\mathrm{ET}_{\mathrm{B}} \mathrm{R}$ antibody specificity was the bronchial smooth muscle of the patient without lung disease (32-34).

After resection, samples were formalin-fixed, dehydrated and paraffin-embedded for immunohistological processing.

Immunohistochemistry. Immunostaining was performed using polyclonal sheep antibodies raised against the $\mathrm{N}$-terminus of human receptors $\mathrm{ET}_{\mathrm{A}} \mathrm{R}$ and $\mathrm{ET}_{\mathrm{B}} \mathrm{R}$ (Alexis Biochemicals, San Diego, CA, USA) (32,35).

Four micrometer-thick sections were mounted on Superfrost Plus Slides (Fisher Scientific, Fairlawn, NJ, USA) and processed for immunohistochemistry. Before $\mathrm{ET}_{\mathrm{A}} \mathrm{R}$ and $\mathrm{ET}_{\mathrm{B}} \mathrm{R}$ staining, specimens were dewaxed, rehydrated and subjected to heat-induced antigen retrieval in a water bath $\left(95^{\circ} \mathrm{C}, \mathrm{pH} 6.0\right.$ with $0.01 \mathrm{M}$ citrate buffer, $\left.40 \mathrm{~min}\right)$. The sections were then incubated for $30 \mathrm{~min}$ in Tris-buffered saline (TBS) with $0.1 \%$ bovine serum albumin. After washing with TBS and incubating for 30 min with $20 \%$ swine serum, sections were exposed for $10 \mathrm{~min}$ to $3 \% \mathrm{H}_{2} \mathrm{O}_{2}$ to block the endogenous peroxidase activity. After an additional wash with TBS, the sections were incubated overnight at $4^{\circ} \mathrm{C}$ with $\mathrm{ET}_{\mathrm{A}} \mathrm{R}$ antibody at a dilution of $1 / 10$ or with $\mathrm{ET}_{\mathrm{B}} \mathrm{R}$ antibody at a dilution of $1 / 50$.

The two antibodies were detected using the Avidin Biotin Peroxidase Complex (ABC) method. After the primary antibody incubation, a biotinylated secondary antibody was applied followed by detection using the LSAB $+{ }^{\circledR}$ system-HRP kit (ref K-0679, DakoCytomation S.A., Trappes, France). The ABC method was used by developing the immunoreaction with diaminobenzidine. Finally, the sections were rinsed in
TBS for $5 \mathrm{~min}$, counterstained with hemalun solution and mounted (RCM 90, Tech-Inter, Maurepas, France).

Negative controls were performed by omitting the primary antibody or, in other slides, by replacing it by a non-specific antibody (DakoCytomation). The staining intensity of malignant cells was graded semi-quantitatively from 1 to 5 as follows: 1, no staining; 2 , detectable staining; 3 , 'mild' staining; 4, 'moderate' staining and 5, 'strong' staining.

Statistical analysis. Quantitative data were expressed as mean \pm standard deviation and median; qualitative data were expressed as frequency and percent. Comparison of staining intensities between the four groups (normal, ADK, SCC and SCLC) was performed using the Kruskal-Wallis nonparametric test, and comparison of $\mathrm{ET}_{\mathrm{A}} \mathrm{R}$ and $\mathrm{ET}_{\mathrm{B}} \mathrm{R}$ staining intensities in each group was performed using a Wilcoxon non-parametric test. A P-value of $<0.05$ was considered statistically significant. Statistical analysis was performed using SAS software v 9.2 (SAS Institute Inc, USA).

\section{Results}

Fig. 1 displays the $\mathrm{ET}_{\mathrm{A}} \mathrm{R}$ and $\mathrm{ET}_{\mathrm{B}} \mathrm{R}$ immunostaining in negative and positive control tissues. Negative controls exhibited no staining (Fig. 1A and B). The staining for $\mathrm{ET}_{\mathrm{B}} \mathrm{R}$ was of strong intensity in bronchial smooth muscle cells (Fig. 1C and E), whereas samples of prostatic adenocarcinoma displayed high $\mathrm{ET}_{\mathrm{A}} \mathrm{R}$ staining intensity (Fig. 1D and F). These observations confirm the specificity of the primary antibodies.

$E T_{A} R$ and $E T_{B} R$ expression in normal samples. In the morphologically normal samples, 80 to $100 \%$ of the ciliated cells from the surface epithelium and $50 \%$ of the serous cells from the submucosal glands displayed a homogeneous cytoplasmic labelling for $\mathrm{ET}_{\mathrm{A}} \mathrm{R}$ and $\mathrm{ET}_{\mathrm{B}} \mathrm{R}$ (Fig. $2 \mathrm{~A}$ and $\mathrm{B}$ ). The staining intensity was higher (usually rated as 'moderate') for $\mathrm{ET}_{\mathrm{A}} \mathrm{R}$ than for $\mathrm{ET}_{\mathrm{B}} \mathrm{R}$ (usually rated as 'clear'). The basal cells usually displayed 'clear to moderate' staining for both receptors. The mucous cells located in the surface epithelium and in the glands were negative for both $\mathrm{ET}_{\mathrm{A}} \mathrm{R}$ and $\mathrm{ET}_{\mathrm{B}} \mathrm{R}$.

$E T_{\mathrm{A}} R$ and $E T_{\mathrm{B}} R$ expression in tumors. When staining was present, 70 to $100 \%$ of the carcinoma cells were positive for $\mathrm{ET}_{\mathrm{A}} \mathrm{R}$ and $\mathrm{ET}_{\mathrm{B}} \mathrm{R}$ (Fig. $2 \mathrm{C}$ and $\mathrm{H}$ ). The immunolabeling patterns of $\mathrm{ET}_{\mathrm{A}} \mathrm{R}$ and $\mathrm{ET}_{\mathrm{B}} \mathrm{R}$ were cytoplasmic and homogeneous in all three types of cancer. All samples of ADK displayed $\mathrm{ET}_{\mathrm{A}} \mathrm{R}$ staining, usually with 'mild to moderate' intensity. Two out of 12 samples were negative for $\mathrm{ET}_{\mathrm{B}} \mathrm{R}$, while the others displayed 'detectable to mild' staining intensity (Table I). Additionally, all SCC samples exhibited $\mathrm{ET}_{\mathrm{A}} \mathrm{R}$ and $\mathrm{ET}_{\mathrm{B}} \mathrm{R}$ staining, usually with 'detectable to mild' intensity for both receptors. Five of the 8 SCLC samples were negative for $\mathrm{ET}_{\mathrm{A}} \mathrm{R}$ staining, while the others displayed a 'detectable to mild' staining. Two of the SCLC samples were negative for $\mathrm{ET}_{\mathrm{B}} \mathrm{R}, 3$ displayed a 'detectable' staining and 2 displayed a 'mild staining'.

There was no statistically significant difference in $\mathrm{ET}_{\mathrm{A}} \mathrm{R}$ staining intensity between normal tissue, ADK and SCC groups. In contrast, $\mathrm{ET}_{\mathrm{A}} \mathrm{R}$ staining in SCLC samples was 

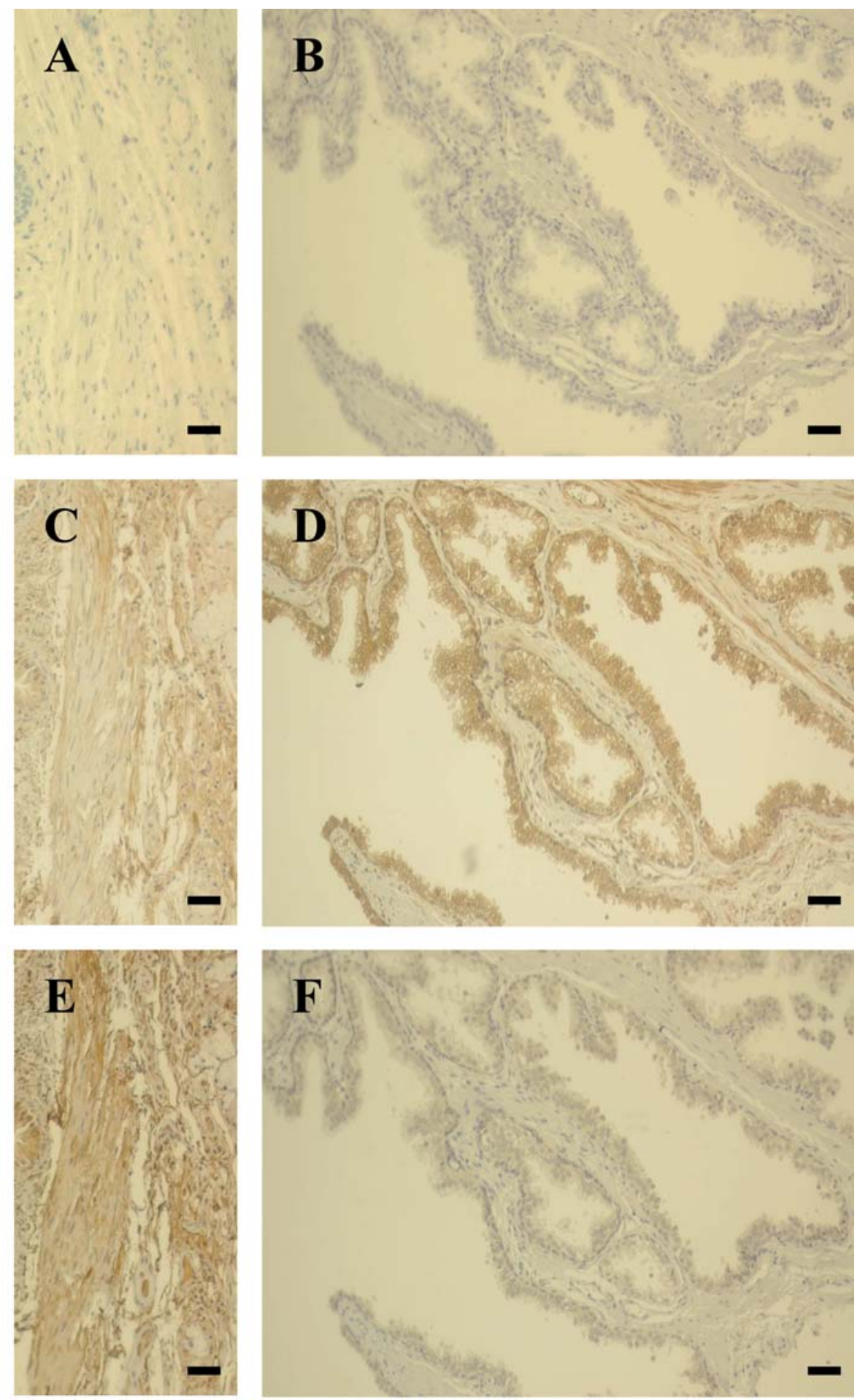

Figure 1. $\mathrm{ET}_{\mathrm{A}} \mathrm{R}$ and $\mathrm{ET}_{\mathrm{B}} \mathrm{R}$ immunostaining in control tissues. The immunostaining was applied to serial sections of human bronchial smooth muscle (A, $\mathrm{C}$ and E) and cancer prostate $(\mathrm{B}, \mathrm{D}$ and $\mathrm{F})$. No primary antibody was used in $\mathrm{A}$ and $\mathrm{B}$. Other sections were exposed to antibodies raised against $\mathrm{ET}_{\mathrm{A}} \mathrm{R}(\mathrm{C}$ and $\mathrm{D})$ or $\mathrm{ET}_{\mathrm{B}} \mathrm{R}$ (E and F). Bars, $50 \mu \mathrm{m}$.

significantly lower than in the three other groups. Additionally, there was no significant difference in $\mathrm{ET}_{\mathrm{B}} \mathrm{R}$ staining intensity between the four groups. $\mathrm{ET}_{\mathrm{A}} \mathrm{R}$ staining intensity was significantly higher than $\mathrm{ET}_{\mathrm{B}} \mathrm{R}$ staining in normal tissue $(\mathrm{P}=0.016)$ and in $\mathrm{ADK}$ samples $(\mathrm{P}=0.015)$. No difference was found between $\mathrm{ET}_{\mathrm{A}} \mathrm{R}$ and $\mathrm{ET}_{\mathrm{B}} \mathrm{R}$ staining intensities in $\mathrm{SCC}$ and in SCLC samples.
Comparison of the ratios of the staining intensities of $\mathrm{ET}_{\mathrm{A}} \mathrm{R}$ and $\mathrm{ET}_{\mathrm{B}} \mathrm{R}$ in each sample revealed differences between the four groups (Table I): the $\mathrm{ET}_{\mathrm{A}} \mathrm{R} / \mathrm{ET}_{\mathrm{B}} \mathrm{R}$ ratio in the SCLC group was significantly lower than in the three other groups $(\mathrm{P}=0.03)$ and the ratio in the ADK group was significantly higher than in the SCC group ( $\mathrm{P}=0.04)$. No statistically significant difference was observed between the SCC or the ADK group and the normal group. 

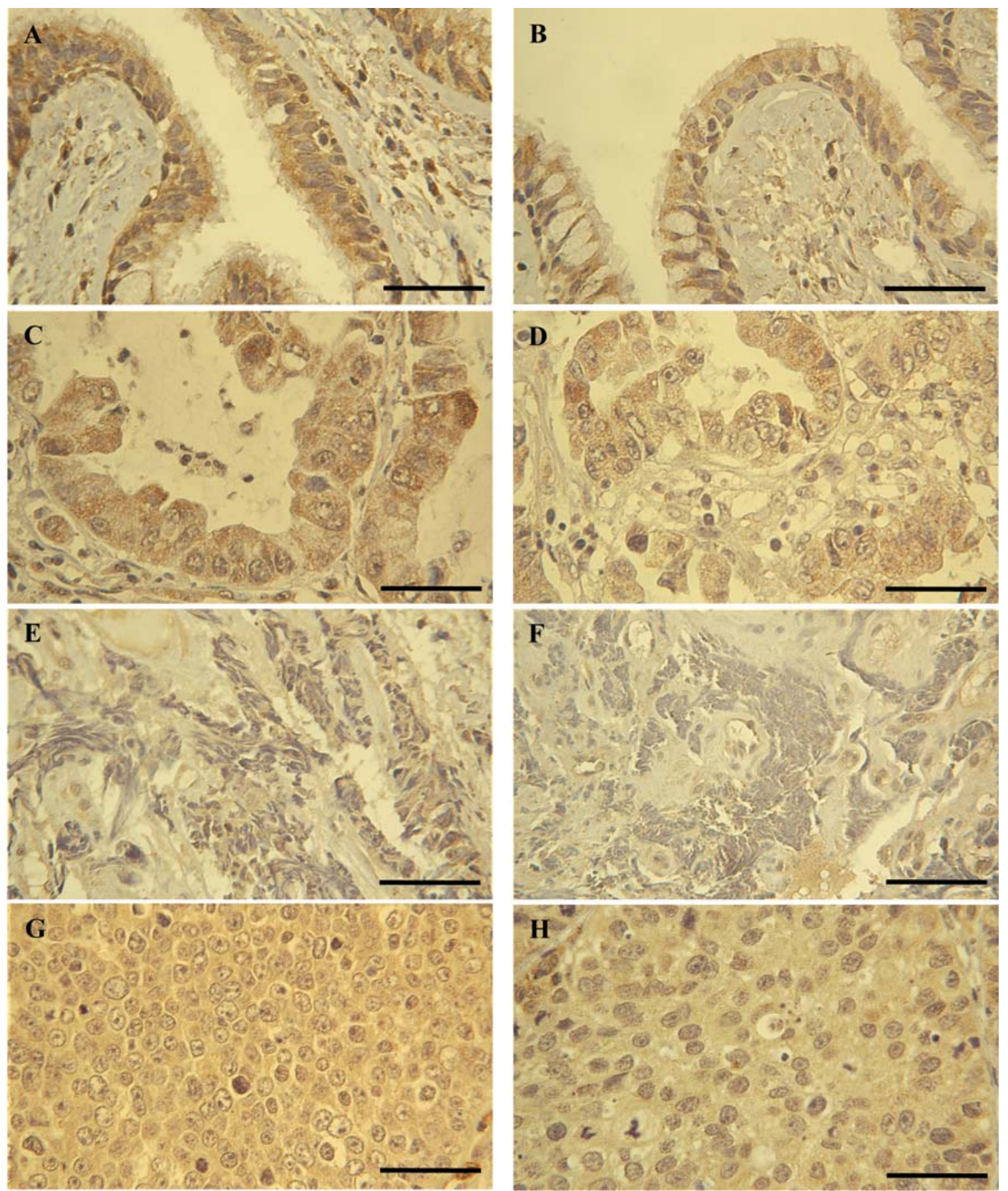

Figure 2. $\mathrm{ET}_{\mathrm{A}} \mathrm{R}$ and $\mathrm{ET}_{\mathrm{B}} \mathrm{R}$ immunostaining in lung cancer tissues. Areas of morphologically normal airway epithelium selected in samples from patients with adenocarcinoma (A and B), areas in adenocarcinoma $(\mathrm{C}$ and $\mathrm{D})$, small cell carcinoma (E and $\mathrm{F})$ and squamous cell carconima $(\mathrm{G}$ and $\mathrm{H})$ samples were immunostained with antibodies raised against $\mathrm{ET}_{\mathrm{A}} \mathrm{R}(\mathrm{A}, \mathrm{C}, \mathrm{E}$ and $\mathrm{G})$ or $\mathrm{ET}_{\mathrm{B}} \mathrm{R}(\mathrm{B}, \mathrm{D}, \mathrm{F}$ and $\mathrm{H})$. Bars, $50 \mu \mathrm{m}$.

Table I. Semi-quantification of the ETR immunostaining intensity in normal and the 3 tumor groups.

\begin{tabular}{lccr}
\hline Group & $\mathrm{ET}_{\mathrm{A}} \mathrm{R}$ & $\mathrm{ET}_{\mathrm{B}} \mathrm{R}$ & $\mathrm{ET}_{\mathrm{A}} \mathrm{R} / \mathrm{ET}_{\mathrm{B}} \mathrm{R}$ \\
\hline Normal $(\mathrm{n}=10)$ & $3.4 \pm 0.7(3.5)$ & $2.6 \pm 0.8(2.5)$ & $1.3 \pm 0.3(1.3)$ \\
$\mathrm{ADK}(\mathrm{n}=12)$ & $3.6 \pm 0.9(4.0)$ & $2.3 \pm 0.9(2.0)$ & $2.0 \pm 1.1(1.7)$ \\
$\mathrm{SCC}(\mathrm{n}=13)$ & $2.7 \pm 0.6(3.0)$ & $2.3 \pm 0.5(2.0)$ & $1.3 \pm 0.4(1.2)$ \\
SCLC $\left(\mathrm{n}=8\right.$ for $\mathrm{ET}_{\mathrm{A}} \mathrm{R}$ and 7 for $\left.\mathrm{ET}_{\mathrm{B}} \mathrm{R}\right)$ & $1.4 \pm 0.5(1.1)$ & $1.8 \pm 0.9(1.5)$ & $0.9 \pm 0.5(0.6)$ \\
\hline
\end{tabular}

Mean \pm standard deviation (median). ADK, adenocarcinoma; SCC, squamous cell carcinoma; SCLC, small cell lung carcinoma; $\mathrm{ET}_{\mathrm{A}} \mathrm{R}$ and $\mathrm{ET}_{\mathrm{B}} \mathrm{R}$, endothelin A and $\mathrm{B}$ receptors, respectively. 


\section{Discussion}

This study evaluated the presence of the endothelin receptors $\mathrm{ET}_{\mathrm{A}}$ and $\mathrm{ET}_{\mathrm{B}}$ by immunohistochemistry in biopsies and samples from patients with various types of lung carcinoma. The staining patterns in morphologically normal lung samples (widespread staining in epithelial cells for both receptors and no $\mathrm{ET}_{\mathrm{A}} \mathrm{R}$ staining and diffuse $\mathrm{ET}_{\mathrm{B}} \mathrm{R}$ staining in bronchial smooth muscle cells) were consistent with previously reported observations (35). Our data demonstrate that $\mathrm{ET}_{\mathrm{A}} \mathrm{R}$ and $\mathrm{ET}_{\mathrm{B}} \mathrm{R}$ are present in almost all samples of lung ADK and SCC, with levels similar to normal tissues; however, the $\mathrm{ET}_{\mathrm{A}} \mathrm{R} / \mathrm{ET}_{\mathrm{B}} \mathrm{R}$ ratio is higher in ADK than in SCC. We also observed the presence of endothelin receptors in SCLC, although $\mathrm{ET}_{\mathrm{A}} \mathrm{R}$ levels and the $\mathrm{ET}_{\mathrm{A}} \mathrm{R} / \mathrm{ET}_{\mathrm{B}} \mathrm{R}$ ratio are lower than in normal tissues and in other tumor types.

Previous studies on the expression of ET receptors in lung carcinomas have provided conflicting results and did not distinguish between different types of lung cancer. Boldrini et al (25) and Ahmed et al (23) studied the expression of $\mathrm{ET}_{\mathrm{A}} \mathrm{R}$ and $\mathrm{ET}_{\mathrm{B}} \mathrm{R}$ mRNA in 201 samples collected from NSCLC patients and in a panel of 7 SCLC and 4 NSCLC cell lines, respectively. Boldrini et al (25) found that $\mathrm{ET}_{\mathrm{A}} \mathrm{R}$ was expressed in $42.5 \%$ of tumor samples vs. $28.5 \%$ for the adjacent normal lung tissue. In contrast, Ahmed et al (23) found that $\mathrm{ET}_{\mathrm{A}} \mathrm{R}$ mRNA was most abundant in the control normal bronchial epithelial cells, with low expression in lung cancer cell lines. The present study revealed that $\mathrm{ET}_{\mathrm{A}} \mathrm{R}$ was present in nearly all samples of normal, ADK and SCC tissue. We found a similar staining intensity in ADK and SCC tumor samples compared to the adjacent normal lung tissue, suggesting that, contrary to several malignancies (20), $\mathrm{ET}_{\mathrm{A}} \mathrm{R}$ is not overexpressed in lung cancer. Moreover, similar to a report by Ahmed et al (23) we found that SCLC displayed no or a weak $\mathrm{ET}_{\mathrm{A}} \mathrm{R}$ signal compared to normal samples. Differences in $\mathrm{ET}_{\mathrm{A}} \mathrm{R}$ immunostaining between non-small cell carcinomas (ADK and SCC) and small cell carcinoma may be linked to the fact that they derive from different lung cells (epithelial and neuroendocrine, respectively). Regarding the expression of $\mathrm{ET}_{\mathrm{B}} \mathrm{R}$, Boldrini et al (25) found that $\mathrm{ET}_{\mathrm{B}} \mathrm{R}$ mRNA was present in half of the lung tumor samples they tested (53\%). In contrast, Ahmed et al (23) and the present study found that the presence of $\mathrm{ET}_{\mathrm{B}} \mathrm{R}$ was widespread in a panel of cell lines and in tumor samples, respectively. Recently, Knight et al (36) found that, due to the silencing of gene promoter by hypermethylation, $\mathrm{ET}_{\mathrm{B}} \mathrm{R}$ mRNA levels were reduced in freshly excised samples of NSCLC compared with normal adjacent lung tissue. In contrast, we found no difference in the $\mathrm{ET}_{\mathrm{B}} \mathrm{R}$ staining intensity between normal tissue and the three groups of tumors. Although decreased $\mathrm{ET}_{\mathrm{B}} \mathrm{R}$ levels have been observed in a majority of malignancies and $\mathrm{ET}_{\mathrm{B}} \mathrm{R}$ has even been reported to be absent in advanced prostate cancer (19), melanoma and colon cancer have been shown to have increased $\mathrm{ET}_{\mathrm{B}} \mathrm{R}$ expression $(37,38)$. Overall, our results demonstrate that the $\mathrm{ET}_{\mathrm{A}}$ and $\mathrm{ET}_{\mathrm{B}}$ receptors are expressed in tumor cells in the main types of human lung carcinomas.
The effect of ET-1 is the result of its combined action on both receptors, leading to separate, overlapping or opposite effects. In tissues where both receptors are present, the comparison of the $\mathrm{ET}_{\mathrm{A}} \mathrm{R} / \mathrm{ET}_{\mathrm{B}} \mathrm{R}$ ratio may be useful to determine the global effect of ET-1. It has been proposed that modifications in the relative levels of $\mathrm{ET}_{\mathrm{A}} \mathrm{R}$ to $\mathrm{ET}_{\mathrm{B}} \mathrm{R}$ in tissues, more precisely an increase in the $\mathrm{ET}_{\mathrm{A}} \mathrm{R} / \mathrm{ET}_{\mathrm{B}} \mathrm{R}$ ratio, can lead to the progression of cells from a normal to a more malignant phenotype $(19,39)$. We found that the $\mathrm{ET}_{\mathrm{A}} \mathrm{R} / \mathrm{ET}_{\mathrm{B}} \mathrm{R}$ ratio differed between the lung cancer types. An increased $\mathrm{ET}_{\mathrm{A}} \mathrm{R} / \mathrm{ET}_{\mathrm{B}} \mathrm{R}$ ratio has previously been reported in ovarian, prostate and breast cancers (20) and in contrast, a decreased $\mathrm{ET}_{\mathrm{A}} \mathrm{R} / \mathrm{ET}_{\mathrm{B}} \mathrm{R}$ ratio has been observed in melanoma (37). If modifications of expression of ET receptors and of the $E_{A} R /$ $\mathrm{ET}_{\mathrm{B}} \mathrm{R}$ ratio are major determinants of the effect of ET-1 on cancer onset and progression, our results suggest that ET-1 may have a different impact on the different lung cancer types.

Our results suggest that endothelin receptor agonists and antagonists could be useful for the treatment of lung cancer. However, to date, there is no clinical assay on the effects of endothelin receptor antagonists on lung cancer. Endothelin receptor antagonists have shown promising preclinical results in prostate and ovarian cancer treatment $(31,40,41)$. In prostate cancer, several phase II and phase III clinical trials with atrasentan (ABT-627) or ZD4054, two highly $\mathrm{ET}_{\mathrm{A}} \mathrm{R}$ selective antagonists, did not demonstrate beneficial effects on time to progression $(40,42-44)$. However, a small but significant positive effect has been observed on survival (44). Another therapeutic strategy is the combination of one endothelin receptor agonist or antagonist with an established anticancer drug. For example, the efficacy of paclitaxel on breast tumor bearing rats was improved by stimulating $\mathrm{ET}_{\mathrm{B}} \mathrm{R}(45)$. In this study, pretreatment with the $\mathrm{ET}_{\mathrm{B}} \mathrm{R}$ agonist IRL 1620 induced the delivery of increased amounts of paclitaxel to the tumor by increasing the blood flow, which caused a significant reduction in tumor volume and in some cases complete remission. Similarly, in a model of nude mice with nasopharyngeal carcinoma cell xenografts, $\mathrm{ET}_{\mathrm{A}} \mathrm{R}$ blockade by atrasentan inhibited the growth of tumor cells, and combined treatment of ABT-627 with the cytotoxic drug cisplatin or 5-fluorouracil produced additive antitumor effects (46). However, a phase I/phase II clinical trial on the effect of atrasentan plus carboplatin and paclitaxel in NSCLC demonstrated the treatment is safe, but has no significant benefit on efficacy and survival (47).

In conclusion, this study shows that $\mathrm{ET}_{\mathrm{A}} \mathrm{R}$ and $\mathrm{ET}_{\mathrm{B}} \mathrm{R}$ are found in nearly all samples from patients with lung carcinoma and that the different types of lung cancer have unique expression patterns. Further investigations are needed to evaluate i) the role of ET-1, ET $\mathrm{A}_{\mathrm{A}} \mathrm{R}$ and $\mathrm{ET}_{\mathrm{B}} \mathrm{R}$ expression on lung cancer prognosis and clinical outcome and ii) the relevance of ETR agonists and antagonists in therapeutic strategies in lung cancer. Our results suggest that the differences in expression of the ET receptors in the various types of lung cancer may impact the efficacy of these molecules. 


\section{Acknowledgements}

We would like to thank the 'Chancellerie des Universités de Paris’ for financial support.

\section{References}

1. Motte S, McEntee K and Naeije R: Endothelin receptor antagonists. Pharmacol Ther 110: 386-414, 2006.

2. Spieker LE, Noll G, Ruschitzka FT and Lüscher TF: Endothelin A receptor antagonists in congestive heart failure: blocking the beast while leaving the beauty untouched? Heart Fail Rev 6: 301-315, 2001

3. Michael JR and Markewitz B: Endothelins and the lung. Am J Respir Crit Care Med 154: 555-581, 1996.

4. Baraniuk JN, Molet S, Mullol J and Naranch K: Endothelin and the airway mucosa. Pulm Pharmacol Ther 11: 113-123, 1998.

5. Marciniak SJ, Plumpton C, Barker PJ, Huskisson NS and Davenport AP: Localization of immunoreactive endothelin and proendothelin in the human lung. Pulm Pharmacol 5: 175-182, 1992.

6. Blouquit S, Sari A, Lombet A, D'Herbomez M, Naline E, Matran R and Chinet T: Effects of Endothelin-1 on epithelial ion transport in human airways. Am J Respir Cell Mol Biol 29: 245-251, 2003

7. Jacobs A, Preston IR and Gomberg-Maitland M: Endothelin receptor antagonism in pulmonary arterial hypertension: a role for selective ET(A) inhibition? Curr Med Res Opin 22: 2567-2574, 2006.

8. Sato K, Oka, M, Hasunuma K, Ohnishi M, Sato K and Kira S: Effects of separate and combined ETA and ETB blockade on ET-1-induced constriction in perfused rat lungs. Am J Physiol 269: L668-L672, 1995.

9. Kizawa Y, Ohuchi N, Saito K, Kusama T and Murakami H: Effects of endothelin-1 and nitric oxide on proliferation of cultured guinea pig bronchial smooth muscle cells. Comp Biochem Physiol C Toxicol Pharmacol 128: 495-501, 2001.

10. Morbidelli L, Orlando C, Maggi CA, Ledda F and Ziche M: Proliferation and migration of endothelial cells is promoted by endothelins via activation of ETB receptors. Am J Physiol 269: H686-H695, 1995.

11. Murlas CG, Gulati A, Singh G and Najmabadi F: Endothelin-1 stimulates proliferation of normal airway epithelial cells. Biochem Biophys Res Commun 212: 953-959, 1995.

12. Ninomiya $H$, Inui $T$ and Masaki T: Paracrine endothelin signaling in the control of basal cell proliferation in guinea pig tracheal epithelium. J Pharmacol Exp Ther 286: 469-480, 1998.

13. Adner M, Cardell LO, Sjöberg T, Ottosson A and Edvinsson L: Contractile endothelin-B (ETB) receptors in human small bronchi. Eur Respir J 9: 351-355, 1996.

14. Daher Z, Noël J and Claing A: Endothelin-1 promotes migration of endothelial cells through the activation of ARF6 and the regulation of FAK activity. Cell Signal 20: 2256-2265, 2008.

15. Morris CD, Rose A, Curwen J, Hughes AM, Wilson DJ and Webb DJ: Specific inhibition of the endothelin A receptor with ZD4054: clinical and pre-clinical evidence. Br J Cancer 92: 2148-2152, 2005.

16. Dupuis J, Stewart DJ, Cernacek P and Gosselin G: Human pulmonary circulation is an important site for both clearance and production of endothelin-1. Circulation 94: 1578-1584, 1996.

17. Bagnato A, Tecce R, Moretti C, Di castro V, Spergel D and Catt KJ: Autocrine actions of endothelin-1 as a growth factor in human ovarian carcinoma cells. Clin Cancer Res 1: 1059-1066, 1995.

18. Asham E, Shankar A, Loizidou M, Fredericks S, Miller K, Boulos PB, Burnstock $G$ and Taylor I: Increased endothelin-1 in colorectal cancer and reduction of tumour growth by ET (A) receptor antagonism. Br J Cancer 85: 1759-1763, 2001.

19. Nelson JB, Chan-Tack K, Hedican SP, Magnuson SR, Opgenorth TJ, Bova GS and Simons JW: Endothelin-1 production and decreased endothelin B receptor expression in advanced prostate cancer. Cancer Res 56: 663-668, 1996.
20. Bagnato A and Natali PG: Endothelin receptors as novel targets in tumor therapy. J Transl Med 2: 16, 2004.

21. Herrmann E, Eltze E, Bierer S, Bogemann M, Brinkmann OA, Balnowair $\mathrm{H}$, Hertle $\mathrm{L}$ and Wülfing $\mathrm{C}$ : Expression of the endothelin-axis in the different histologic subtypes of renal cell carcinoma: a tissue microarray analysis. Oncol Rep 17: 275-280, 2007.

22. Wülfing C, Eltze E, Yamini J, Bierer S, Böcker W, Hertle L, Semjonow A and Sievert KD: Expression of the endothelin axis in bladder cancer: relationship to clinicopathologic parameters and long-term survival. Eur Urol 47: 593-600, 2005.

23. Ahmed SI, Thompson J, Coulson JM and Woll PJ: Studies on the expression of endothelin, its receptors subtypes, and converting enzymes in lung cancer and in human bronchial epithelium. Am J Respir Cell Mol Biol 22: 422-431, 2000.

24. Giaid A, Hamid QA, Springall DR, Yanagisawa M, Shinmi O, Sawamura T, Masaki T, Kimura S, Corrin B and Polak JM: Detection of endothelin immunoreactivity and mRNA in pulmonary tumours. J Pathol 162: 15-22, 1990.

25. Boldrini L, Gisfredi S, Ursino S, Faviana P, Lucchi M, Melfi F, Mussi A, Basolo F and Fontanini G: Expression of endothelin-1 is related to poor prognosis in non-small cell lung carcinoma. Eur J Cancer 41: 2828-2835, 2005.

26. Carpagnano GE, Foschino-Barbaro MP, Resta O, Gramiccioni E and Carpagnano F: Endothelin-1 is increased in the breath condensate of patients with non-small-cell lung cancer. Oncology 66: 180-184, 2004.

27. Pickering V, Jordan RC and Schmidt BL: Elevated salivary endothelin levels in oral cancer patients: A pilot study. Oral Oncol 43: 37-41, 2007.

28. Grant K, Knowles J, Dawas K, Burnstock G, Taylor I and Loizidou M: Mechanisms of endothelin 1-stimulated proliferation in colorectal cancer cell lines. Br J Surg 94: 106-112, 2007.

29. Sumitomo M, Shen R, Walburg M, Dai J, Geng Y, Navarro D, Boileau G, Papandreou CN, Giancotti FG, Knudsen B and Nanus DM: Neutral endopeptidase inhibits prostate cancer cell migration by blocking focal adhesion kinase signaling. J Clin Invest 106: 1399-1407, 2000.

30. Bagnato A, Rosano L, Spinella F, Di Castro V, Tecce R and Natali PG: Endothelin B receptor blockade inhibits dynamics of cell interactions and communications in melanoma cell progression. Cancer Res 64: 1436-1443, 2004.

31. Rayhman O, Klipper E, Muller L, Davidson B, Reich R and Meidan R: Small interfering RNA molecules targeting endothelinconverting enzyme-1 inhibit endothelin-1 synthesis and the invasive phenotype of ovarian carcinoma cells. Cancer Res 68: 9265-9273, 2008.

32. Wülfing P, Kersting C, Tio J, Fischer RJ, Wülfing C, Poremba C, Diallo R, Böcker W and Kiesel L: Endothelin-1-, endothelin-A-, and endothelin-B-receptor expression is correlated with vascular endothelial growth factor expression and angiogenesis in breast cancer. Clin Cancer Res 10: 2393-2400, 2004.

33. Knott PG, D'Aprile AC, Henry PJ, Hay DW and Goldie RG: Receptors for endothelin-1 in asthmatic human peripheral lung. Br J Pharmacol 114: 1-3, 1995.

34. Goldie RG, Henry PJ, Knott PG, Self GJ, Luttmann MA and Hay DW: Endothelin-1 receptor density, distribution, and function in human isolated asthmatic airways. Am J Respir Crit Care Med 152: 1653-1658, 1995.

35. Faisy C, Pinto F, Danel C, Naline E, Risse PA, Leroy I, Israel-Biet D, Fagon JY, Candenas ML and Advenier C: Beta2adrenoceptor agonist modulates endothelin-1 receptors in human isolated bronchi. Am J Respir Cell Mol Biol 34: 410-416, 2006.

36. Knight LJ, Burrage J, Bujac SR, Haggerty C, Graham A, Gibson NJ, Ellison G, Growcott JW, Brooks AN, Hugher AM, Xinarianos G, Nikolaidis G, Field JK and Liloglou T: Epigenetic silencing of the endothelin-B receptor gene in non small cell lung cancer. Int J Oncol 34: 465-471, 2009.

37. Demunter A, De Wolf-Peeters C, Degreef H, Stas M and Van den Oord JJ: Expression of the endothelin-B receptor in pigment cell lesions of the skin. Evidence for its role as tumor progression marker in malignant melanoma. Virchows Arch 438: 485-491, 2001.

38. Egidy G, Juillerat-Jeanneret L, Jeannin JF, Korth P, Bosman FT and Pinet F: Modulation of human colon tumor-stromal interactions by the endothelin system. Am J Pathol 157: $1863-1874,2000$ 
39. Bagnato A, Spinella F and Rosano L: The endothelin axis in cancer: the promise and the challenges of molecularly targeted therapy. Can J Physiol Pharmacol 86: 473-484, 2008.

40. Lalich M, McNee DG, Wilding G and Liu G: Endothelin receptor antagonists in cancer therapy. Cancer Invest 25: 785-794, 2007.

41. Rosano L, Di Castro V, Spinella F, Decandia S, Natali PG and Bagnato A: ZD4054, a potent endothelin receptor A antagonist inhibits ovarian carcinoma cell proliferation. Exp Biol Med (Maywood) 231: 1132-1135, 2006.

42. Carducci MA, Nelson JB, Bowling MK, Rogers T, Eisenberger MA, Sinibaldi V, Donehower R, Leahy TL, Carr RA, Isaacson JD, Janus TJ, Andre A, Hosmane BS and Padley RJ: Atrasentan, an endothelin-receptor antagonist for refractory adenocarcinomas: safety and pharmacokinetics. J Clin Oncol 20: 2171-2180, 2002 .

43. Nelson JB, Love W, Chin JL, Saad F, Schulman CC, Sleep DJ, Qian J, Steinberg J, Carducci M and Atrasentan phase 3 study group: Phase 3, randomized, controlled trial of atrasentan in patients with nonmetastatic, hormone-refractory prostate cancer. Cancer 113: 2478-2487, 2008.
44. James ND, Caty A, Borre M, Zonnenberg BA, Beuzeboc P, Morris T, Phung D and Dawson NA: Safety and efficacy of the specific endothelin-A receptor antagonist ZD4054 in patients with hormone-resistant prostate cancer and bone metastases who were pain free or mildly symptomatic: a double blind, placebo-controlled, randomised, phase 2 trial. Eur Urol 55: 1112-1123, 2009

45. Rajeshkumar NV, Rai A and Gulati A: Endothelin B receptor agonist, IRL 1620, enhances the anti-tumor efficacy of paclitaxel in breast tumor rats. Breast Cancer Res Treat 94: 237-247, 2005. 46. Mai HQ, Zeng ZY, Feng KT, Ye YL, Zhang CQ, Liang WJ, Guo X, Mo HY and Hong MH: Therapeutic targeting of the endothelin A receptor in human nasopharyngeal carcinoma. Cancer Sci 97: 1388-1395, 2006.

47. Chiappori AA, Haura E, Rodriguez FA, Boulware D, Kapoor R, Neuger Am, Lush R, Padilla B, Burton M, Williams C, Simon G, Antonia S, Sullivan DM and Bepler G: Phase I/II study of atrasentan, an endothelin A receptor antagonist, in combination with paclitaxel and carboplatin as first-line therapy in advanced non-small cell lung cancer. Clin Cancer Res 14: 1464-1469, 2008. 